IJ§ER

ISSN: 2149-5939
International Journal of Social Sciences and Education Research

Online, http://dergipark.gov.tr/ijsser

Volume: 4(1), 2018

\title{
Correlation between education and workmanship: A case study of Muslim artisans of Aligarh lock industry
}

\author{
Talmeez Fatma Naqvi ${ }^{1}$
}

\author{
Shaikh Abul Barkat ${ }^{2}$
}

Accepted Date: 30 / $10 / 2017$

\begin{abstract}
India's economic growth cannot be conceived in isolation of its household and tiny level industry such as the Aligarh lock industry. It is more so as the growth of India's petty industrial units has not at par with the over all, rather rapid economic growth of the country and the artisans engaged in the household and tiny level units have also not been equally benefitted with the consequential profits. The Muslims who constitute large number of artisan class have particularly been at a loss as they tend to excessively concentrate in the low-paying jobs, engage in artisanal sectors, or else serve as casual labour. Most of them are self-employed in low income artisan based works. Above all, they are educationally more backwards than their counterparts in other communities. Restrained further by over all security scenario all this goes to curtail their mobility. The present field based study that ascertains the status of Muslim artisans of Aligarh lock industry brings forth the fact that the artisans have been struggling hard for sustaining with the bare minimum of resources (income), yet aspiring to stick to the same hereditary profession. Availing of educational facilities is a far cry for them. Yet, they like to expose their children to formal education, even though it looks the least beneficial to them. This takes us to the next stage: how to improve their lot through educational means that could be geared to provide craft centred education to them all and educate them in the art of marketing their product, a more profitable step for raising levels of income.
\end{abstract}

Keywords: Lock Industry, Muslim Artisans, educational status of artisans, reasons of educational backwardness, socio-political condition of Muslim artisans

\section{Introduction}

The rapid economic growth - over six percent GDP growth since the 1980s (IHD, 2014, p. 1) - has given India a heightened status in the global economy. Yet, the benefits of economic development have not improved the quality of life of a vast number of socio-religious groups which remain largely conditioned by structurally and historically defined exploitative contexts. Due to the persistent conditions of structural disparity and social inequality, the economic development boom may hardly generate desired social change and class mobility at an equal rate for all social classes, caste groups, and religious minorities. Muslim community is at the heart of this paradox. Accounting for 14.4 percent of India's vast population, making it the largest of all religious minorities in India, the community has been the subject of considerable development discourse, for it has the lowest levels of educational attainment when compared with major socioreligious groups in India and the lowest standard of living in the country (see Ghosh, 2013). Research indicates that Muslims, on average, spend 32.7 rupees per day, whereas Sikhs spend 55.3, Christians 51.4, and Hindus 37.5 rupees (Ghosh, 2013). Muslims' contribution being 11.2 percent

\footnotetext{
${ }^{1}$ Asst. Prof. Dr., College of Teacher Education Bhopal, Maulana Azad National Urdu University, Email: naqvitalmeez@gmail.com

${ }^{2}$ Dr., Regional Director, Mumbai Regional Centre, Maulana Azad National Urdu University, Email: abulbarkat_2006@yahoo.co.in
} 
Naqvi, T.F., Barkat, S. A. (2018). Correlation between education and workmanship: A case study of Muslim artisans of Aligarh lock industry. International Journal of Social Sciences and Education Research, 4(1), 4148.

to the country's overall GDP growth is relatively low as compared to that of the Dalits and Adivasi (indigenous groups defined as Scheduled Tribes or ST), contributing at 16.5 percent (Times of India, 2013). Its major cause lies in their being excessively concentrated in the low-paying jobs. They are mostly self-employed and engaged in artisanal sectors, or else serving as casual labour. Although a copious number of schemes by Government of India and the non-Government organizations took measures aimed at transforming Muslims' social and economic condition but unfortunately these remains notably unchanged. The root cause lies in their educational backwardness and remains true even after the attempts having been made to improve their educational conditions.

In a discussion paper based on research evidence, Humayun Kabir (2016) reported that despite structural constraints, Muslims and other backward classes have responded to the processes of economic and social change in which education is a significant factor (Jeffrey, Jeffery, and Jeffery, 2004). In north India, and especially in Uttar Pradesh, not only Muslims but also other disadvantaged groups have failed to secure salaried employment and "respectable jobs," which often refers to government jobs. Compared to the Dalits, Muslims have a greater tendency to depend on local wage labour and artisanal work, which pay low salaries and have been less successful in obtaining educational credentials and securing regular salaried jobs (Jeffrey et al., 2005, p. 2090). Unlike Dalit youths, Muslim youths are less visible in wider Indian society when translating their social frustration into political activism. What distinguishes Muslims from Dalits is that, when pushed out of formal and regular jobs, they tend to form a "minority enclave labour market" characterized by self-employment, casual labour, and low-paying local artisanal work (Das, 2008). This pattern, resulting from lack of land ownership, appropriate educational credentials, social networks, and cultural capital, continues to reproduce ghettoization and the differences between Muslims and other social classes.

The dearth of scholarship and robust empirical evidence on how social, political, and cultural forces interact in such a way as to restrict social change and sustain the status quo has compelled researchers to depend on tabulated numerical representations of Muslim community in India. Widely held public perceptions often pinpoint religious and cultural conservatism as causal factors of the Muslim community's backwardness. However, recent scholarship and several government reports suggest that the interplay of political, cultural, social, and economic forces continues to produce and reproduce the differences between Muslims and other social and religious communities in India (see GOI, 2006; Das, 2008), thereby challenging the broader public perception that tends to blame the Muslim community for its own poverty. The Sachhar Committee Report, a widely circulated and much-quoted study by a government commission, captures multifaceted factors associated with the political, cultural, and social problems that Muslims face in everyday life (GOI, 2006; Basant, 2007). Although many of these factors are also equally applicable to other backward social and religious communities, what distinguishes the Muslims from other groups is a political and cultural sense of alienation from mainstream Indian society. Historically defined political conditions, sensitivity to communalism in political campaigns and discourses, and the construction of Indian nationalism in close connection to the notions of "Hindu" land poses a serious political question to Muslims: "Can a Muslim be Indian?" (Pandey, 1999). In this political condition, "Muslims carry a double burden of being labeled as "anti-national" and as being "appeased" at the same time" (GOI, 2006, p. 11). Issues of insecurity and vulnerability push many Muslims to live in a particular location, and therefore Muslim "ghettoization" is markedly 
Naqvi, T.F., Barkat, S. A. (2018). Correlation between education and workmanship: A case study of Muslim artisans of Aligarh lock industry. International Journal of Social Sciences and Education Research, 4(1), 4148.

visible in housing, schooling, and jobs (GOI, 2006, p. 14; Basant, 2007, p. 828). Low representation in public and private regular employment sectors, collective alienation, perceptions of discrimination in government employment, lack of security, and suspicion of Muslims among state apparatuses and agencies tend to reproduce this process of ghettoization, causing Muslims to attach less importance to formal secular education and preventing them from translating their education into respectable and desirable jobs. Moreover, many Muslims find that making the effort to learn Urdu, a marker of their cultural and religious tradition, presents another limitation within the context of school textbooks and communities that use a different language (GOI, 2006, pp. 14-15; Basant, 2007, pp. 828-829). This is one of the reason Muslims have developed a tendency to depend on local wage labour and artisanal work, which pay low salaries. If we see any artisans' work whether it is chikan kari, dardozi, woodwork, handloom work, lock industry hand tools industry we may find excessive Muslim concentration.

Amongst the artisan based work places we come across Aligarh lock Industry situated in U.P. Aligarh is famous for its Muslim University and lock industry. Aligarh's locks provide security and sense of security to millions of houses in India and neighbouring countries. According to the 2011 Census, the total population of Aligarh district is 12, 74,408. More than 2 lakh people (around 15.7 per cent) are associated, directly or indirectly, with at least 5,000 lock manufacturing units. Muslims form the majority of artisans in the industry whereas big manufacturing units and business houses are owned by both, Hindus and Muslims. Muslims artisans manufacture about 80 per cent of locks of Aligarh. As labourer-artisans they manufacture goods for big players. They are artisans by heredity. All the family members are engaged as labourer-artisans and involved in the process of lock making. At the same time they prepare their next generations artisan-labourers. Although a central University with minority character and dozens of schools are located in their surroundings but they seem to have put their self made locks on the doors, against the educational opportunities which are available on their doorsteps. The question however remains as to why and to what extent they lag behind in education. To find the answers a survey was done with the following objectives in mind.

\section{Objectives of the study}

- To examine the educational status of the artisans of lock manufacturing industry.

- To investigate the causes of educational backwardness.

- To analyze the problems or hurdles in getting Education.

- To suggest the measures for educational improvement and income enhancement

\section{Methodology}

The study was qualitative in nature. The data was collected from different wards of Aligarh city.

\subsection{The sample}

The study was conducted in the mohallas of Aligarh namely, Rasalganj, Sarai Rehman, Usman Para, Jeevan Garh, Atish Bazan, Delhi Gate, Bhojpura, Shahjamal, Hathi Pul, Tantanpara and Chowk Bundu Khan. In all, 1154 respondents were contacted. 
Naqvi, T.F., Barkat, S. A. (2018). Correlation between education and workmanship: A case study of Muslim artisans of Aligarh lock industry. International Journal of Social Sciences and Education Research, 4(1), 4148.

\subsection{Tools of the study}

The study is, in main, based on primary data collected through field surveys. Household level survey was conducted in through the questionnaire based interviews. The interview was mainly focussed on their educational status and causes of educational backwardness.

\subsection{Data collection}

For data collection interview model was chosen. This enabled and facilitated asking questions, elicit answers, uncover perspectives and notions, and give the subjects the opportunity in which to give meaning to their respective roles.

\subsection{Analysis and discussion}

After conducting the interviews and having taken field notes it was found that the lock industry employed three categories of workers that are regular, casual, and family workers. The family workers in household units included family members sharing kitchen and some relatives who were paid for the job. Almost all the workers were reported to be more than 16 years of age and thus happened to be adults. The incidence of child labour as reported was found to be very nominal. It may however be mentioned that the figure about number of children engaged as reported by the respective units was presumably much less than the actual number working in the industry. When researcher entered the units she noticed the children working with adults. But owners immediately asked the children to stop working and go inside. It was purported that the children had come to meet their parents. The unit owners were conscious of the fact that they are not allowed to employ child labour. They, therefore, did not appreciate any inquiry related to child labour.

Literacy is generally considered an important condition for both acquisitions of technical skills as well as for upward occupational mobility. The lock industry had large number ( 72 per cent) illiterate workers. Only 15 per cent of the workers had education up to primary level and another 13 per cent were middle pass. Not even a single worker in household units of the industry had graduation degree. 90 per cent of the women were illiterate and, not a single woman has studied beyond primary level of education. A very few, (just one per cent) could read and write and claimed to have passed primary level examination. The female children worked at household units, the girls helped the parents in family occupations after the school hours or after completing cooking, washing and other household works.

In regards to the reason of not getting education, the respondents of the study reported a number of reasons. Amongst them the prominent ones were the poor quality of schools, pathetic, noncooperative and idle teachers. The state's institutional discrimination against Muslims is an undeniable presumption. State investment in education in Muslim-dominated areas has been pathetic. Muslims have also not sufficiently benefited from various government schemes meant for general educational and economic advancement.

A very interesting thing reported by a number of respondents was that ' we will neither get admissions in the good institutions nor get jobs only because of our belongingness to a particular religion then why should we waste our time and energy'. One respondent convinced the researcher in a very informed way, 'madam! We are born as a labourer and will die as a labourer only'. Muslims routinely argue that despite possessing adequate educational qualifications they are not employed in government services, and point out that Muslim representation in the services is 
Naqvi, T.F., Barkat, S. A. (2018). Correlation between education and workmanship: A case study of Muslim artisans of Aligarh lock industry. International Journal of Social Sciences and Education Research, 4(1), 4148.

much less than that warranted by their proportion in population. What is the use, many Muslims ask, of investing in their children's higher education if they are refused government employment simply because of their religion? In the private sector, too, Muslims, like Dalits, believe that discrimination continues unabated, further dampening their enthusiasm for higher education. This has led to demands by some Muslim organisations for reservations for Muslims, either as a single category or for backward caste Muslims, in government jobs and in educational institutions.

Poverty, overall non-conducive environment for learning, lack of assistance for children in homes and the schools non- supportive attitude towards them were other reasons that the workers underlined. That was why that even if they get their children enrolled in schools. they leave the schools midway. Hence the dropout rate is a bit high. In addition, the neo-liberal economic policies of the last two decades or so have hit various Muslim artisan communities across the country, rather severely. Mounting economic marginalisation and deprivation naturally make higher education an impossible proposition for many Muslim families.

Given their poverty and the feeling of discrimination in both private and public sector employment and education institutions, many Muslims feel it is enough for their children to receive basic education before seeking some sort of petty self-employment to contribute to the family upkeep. These facts account for the higher dropout rate among school-going Muslims children at all levels as compared to other religious communities. Periodic riots in places where Muslims have witnessed some degree of economic progress have resulted in pushing large sections of the community against the wall, leading to a process of ghettoisation and further strengthening insularity and religious conservatism. Even the Muslim religious scholars (Ulema) take little interest in the realworld concerns of ordinary Muslims, focusing instead on religious, symbolic or identity-related issues.

It was also felt by the researcher that deep-rooted upper caste prejudices, pre-colonial ruling elites (Muslim and Hindu) took little or no interest in the development of lower segments Muslim community. The historical record reveals a deep-rooted contempt displayed for indigenous Muslim converts (profession based castes, in main) by the Muslim nobility or shurafa, who claimed foreign descent. Like other Dalit and low caste groups, these Muslim segments remained educationally deprived. In other words, the caste-class based constraints of many Indian Muslims explain, in part, the overall educational marginalisation of the community today. The partition in 1947 also had momentous consequences for Muslim education. In its wake the bulk of the modern-educated north Indian Muslim middle class shifted to Pakistan, leaving behind millions of economically and educationally deprived co-religionists.

Before 1947, the north Indian middle-class, particularly the products of the Aligarh Muslim University, had played a key role in promoting modern education. In the absence of a class that championed liberal or progressive causes, the prospects for education turned out to be bleak. There was also the fear, not entirely unfounded, that government schools, with their Hindu-oriented syllabus and alleged anti-Muslim bias, would result in de-Islamisation of Muslim children.

Another reason for the overall educational marginalisation of the Muslim community, particularly in north India, is the fact that the community is deeply divided within, and lack political leadership. The Muslim community, particularly in north India, where most Muslims live, is bereft of a substantial educated middle class. This has allowed Muslim clerics or ulema to assert their claim of being its spokesmen as well as the defenders of Islam and Muslim identity. They 
Naqvi, T.F., Barkat, S. A. (2018). Correlation between education and workmanship: A case study of Muslim artisans of Aligarh lock industry. International Journal of Social Sciences and Education Research, 4(1), 4148.

are backed by various political parties, who use them to garner nothing but Muslim vote. This is also a reaction to Hindu chauvinism, with Hindutva groups also deliberately raking up such issues to create a Hindu vote-bank and to keep Muslims on the defensive, giving them little space to think of their economic and educational concerns or to demand their rights from the state. Consequently, since education, particularly of the marginalised, is not a prime concern of the so called existing Muslim leadership, particularly in north India, Muslims have not been active in setting up community-based educational institutions in sufficient number.

Talk of a hidden nexus between political parties, even those that claim to be secular, Muslim political and religious leaders and Hindutva groups, all with vested interests in keeping Muslim educational and economic issues out of political discourse, is thus not unwarranted.

The measures to be taken up for up-lifting the lot of Muslim artisans may include general strategy as well as specific steps of concrete nature.

The artisan community of lock industry of Aligarh is struggling hard to compete with international players in the era of today's globalization. Large number of Muslim lock workers has lost jobs in the past few years in face of cheaper Chinese locks. If these artisans have to survive in the present era, their upliftment is an essential condition.

Due to forces of competitive market and globalization and also due to deteriorating socioeconomic condition of master craftsmen/artisan these skills are not being pursued by the young generation productively. Government of India is of firm conviction that the traditional craftsmanship is needed to be preserved. There is a need to augment traditional arts and entrepreneurial skill which are the backbone of cottage and small scale industry and establish better market linkages enhance branding and ensure access to credit.

Need persists for inculcating trust in the Muslim artisans so as they may come to believe that they are as good Indians as others. They need to be empowered psychologically. This may be done by roping in psychologists and social scientist. The NGOs may also be involved to work at the grass-root level.

Some success stories and case studies of Muslims as well as other artisans may be presented and demonstrated in the related areas. Such stories may motivate for upward social mobility.

With the purpose of enhancing levels of income, technical side of workmanship need to be linked with the marketing of the finished product. This linkage will correlate need for education with the idea of marketing.

Education of girls has to be given top priority. They need to be provided with required facilities in their immediate neighbourhood having female teachers.

Craft oriented education may be arranged for the children, youngsters as well as craft persons' children mainly because craftsmanship is virtually hereditary profession. Adult education centres having specific provisions for craft centred learning and reorientation may be established in the neighbourhood of artisans' settlements/mohallas, etc. Such centres should provide instructions as are linked with the artisans' job requirements.

\section{Conclusions and recommendations}


Naqvi, T.F., Barkat, S. A. (2018). Correlation between education and workmanship: A case study of Muslim artisans of Aligarh lock industry. International Journal of Social Sciences and Education Research, 4(1), 4148.

In north India, and particularly in Uttar Pradesh Muslims and other disadvantaged sections of society have a greater leaning to depend on local wage labour and artisanal work, which pay low salaries and have been less successful in obtaining educational qualifications and securing regular and white collared salaried jobs. If we see any artisans' work whether it is chikan kari, dardozi, woodwork, handloom work, lock industry hand tools industry we may find excessive Muslim concentration. Aligarh is famous for its Muslim University and lock industry. Aligarh's locks provide security and sense of security to millions of houses in India and neighbouring countries. But the workers of this industry are living a insecure life. Education is still a distant dream of the workers of this industry had large number (72 per cent) illiterate workers. Only 15 per cent of the workers had education up to primary level and another 13 per cent were middle pass. 90 per cent of the women were illiterate and, not a single woman has studied beyond primary level of education. Poor quality of schools, pathetic, non-cooperative and idle teachers, poverty, overall nonconducive environment for learning, lack of assistance for children in homes and the schools nonsupportive attitude towards them were other reasons of educational backwardness of Muslims.

There is urgent need to the measures be taken up for up-lifting the lot of Muslim artisans may include general strategy as well as specific steps of concrete nature.

\section{References}

Basant, Rakesh. (2012). Education and employment among Muslims in India: An analysis of patterns and trends. Working Paper No.20, Ahmedabad: Indian Institute of Management.

Basant, Rakesh. (2007). Social, economic and educational conditions of Indian Muslims. Economic and Political Weekly, Vol.42 (10): 828-832.

Bourdieu, Pierre. (1974). The school as a conservative force: Scholastic and cultural inequalities. In Eggleston, J. (ed.), Contemporary Research in the Sociology of Education, pp.32-46, London: Methuen.

Bourdieu, Pierre and Passeron, Jean-Claude. (1977). Reproduction in education, Society, and Culture. Trans. Richard Nice, London: Sage.

Census of India (COI). (2015a). Aligarh city census 2011 data. Retrieved Jan 4, 2017 from http://www.census2011.co.in

Census of India (2011). Distribution of population by religions. Drop-in Article on Census-No.4. Retrieved Nov. 10, 2014 from Retrieved Jan 4, 2017 from http://www.census2011.co.in

Das, Maitreyi Bordia. (2008). Minority status and labor market outcomes: Does India have minority enclaves? Policy Research Working Paper 4653, The World Bank, South Asia Region, Retrieved Retrieved Jan 4, 2017 from http://www.census2011.co.in

Ghosh, Polash. (2013). Surprise, surprise: Muslims are India's poorest and worst educated religious group. Retrieved Jan 4, 2017 from http://www.ibtimes.com/surprise-surprise-muslims-are-indias-poorestworst-educated-religious-group-1392849

Government of India (GOI). (2006). Social, economic, and educational status of the Muslim community of India. New Delhi: Cabinet Secretariat, Govt. of India.

Hindu, The. (2015, Aug 25). Muslim population growth slows. Retrieved Jan 4, 2017 from http://www.census2011.co.in from http://www.thehindu.com/news/national/census-2011-data-on-population-by-religious-communities/article7579161.ece

Humayun Kabir (2016) From School to Work: Muslim Youths' Education and employment Strategies in a Community in Uttar Pradesh, India discussion paper by institute of developing economies

Institute for Human Development (IHD). (2014). India labor and employment report: Workers in the era of globalization. New Delhi: Academic Publication 
Naqvi, T.F., Barkat, S. A. (2018). Correlation between education and workmanship: A case study of Muslim artisans of Aligarh lock industry. International Journal of Social Sciences and Education Research, 4(1), 4148.

Jeffery, Patricia and Jeffery, Roger. (2002). A population out of control? Myths about Muslim fertility in contemporary India. World Development, Vol.30 (10): 1805-1822.

Jeffrey, Craig. (2010). Timepass: Youth, class, and the politics of waiting in India. Stanford, California: Stanford University Press.

Jeffrey, Craig, Jeffery, Patricia and Jeffery, Roger. (2008a). Degrees without freedom? Education, masculinities, and unemployment in north India. Stanford, California: Stanford University Press.

Jeffrey, Craig, Jeffery, Roger, and Jeffery, Patricia. (2008b). School and madrasah education: Gender and the strategies of Muslim young men in rural north India. Compare, Vol. 38 (5): 581-593.

Jeffrey, Craig, Jeffery, Roger, and Jeffery, Patricia. (2005). The mother's lap and the civilizing mission: Madrasah education and rural Muslim girls in western Uttar Pradesh. In Zoya Hasan and Ritu Menon (eds.), The Diversity of Muslim Women's Lives in India, pp.91-134, Piscataway, NJ: Rutgers University Press.

Jeffrey, Craig, Jeffery, Roger, and Jeffery, Patricia. (2005). Reproducing difference? Schooling, jobs, and empowerment in Uttar Pradesh, India. World Development, Vol. 33 (12): 2085-2101.

Jeffrey, Craig, Jeffery, Roger, and Jeffery, Patricia. (2004). “A useless thing!” or "nectar of the Gods”? The cultural production of education and young men's struggle for respect in liberalizing north India. Annals of the Association of American a Muslim be Indian? Comparative Study of Society and History, Vol. 41 (4): 608-629.

Ministry of Human Resource Development (MoHRD). (2013). Report of the standing committee of the National Monitoring Committee for Minorities' Education (NMCME). New Delhi: MoHRD, Govt. of India.

Pandey, G. (1999). Can a Muslim be Indian? Comparative studies in society and history. 41, 4 . October 1999. P 617.

Times of India, The. (2013, Jan 14). Have government schemes failed Muslims? Retrieved Jan 12, 2016 from http://timesofindia.indiatimes.com/india/Have- Geographers, Vo.94 (4): 961-981. 